\title{
The Effect of Corporate Integrity on Stock Price Crash Risk*
}

\author{
Hong YIN**, Ruonan ZHANG*** \\ Received: September 14, 2019 Revised: November 01, 2019 Accepted: January 05, 2020
}

\begin{abstract}
Purpose: This research aims to investigate the impact of corporate integrity on stock price crash risk. Research design, data, and methodology: Taking 1419 firms listed in Shenzhen Stock Exchange in China as a sample, this paper empirically analyzed the relationship between corporate integrity and stock price crash risk. The main integrity data was hand-collected from Shenzhen Stock Exchange Website. Other financial data was collected from CSMAR Database. Results: Findings show that corporate integrity can significantly decrease stock price crash risk. After changing the selection of samples, model estimation methods and the proxy variable of stock price crash risk, the conclusion is still valid. Further research shows that the relationship between corporate integrity and stock price crash risk is only found in firms with weak internal control and firms in poor legal system areas. Conclusions: Results of the study suggest that corporate integrity has a significant influence on behaviors of managers. Business ethics reduces the likelihood of managers to overstate financial performance and hide bad news, which leads to the low likelihood of future stock price crashes. Meanwhile, corporate integrity can supplement internal control and legal system in decreasing stock price crash risks.
\end{abstract}

Keywords: Integrity, Stock Price Crash Risk, Agency Cost

JEL Classification Code: G12, G14, M41

\section{Introduction}

Market economy is essentially a contractual economy. Law and reputation are two basic mechanisms in maintaining the orderly operation of market economy (Zhang, 2001). Reputation or trust is the moral basis of market economy and one main social capital that determines economic growth and social progress (Zhang \& $\mathrm{Ke}, 2002)$. In order to improve market credit environment, the Central Committee of China and the State Council have issued a number of policies to encourage the construction of social credit system. In response to the call, practitioners

*This paper was supported by talent introduction project of Suzhou Vocational University (No.3180138).

${ }^{* *}$ First Author, Associate Professor, Department of Accounting, Business School, Suzhou Vocational University, China, Email: yinhongcdlg@163.com

${ }^{* * *}$ Corresponding Author, Assistant Professor, Department of International Trade, Business School, Suzhou Vocational University, China, Email: zhrn3700@163.com

๑ Copyright: Korean Distribution Science Association (KODISA)

This is an Open Access article distributed under the terms of the Creative Commons Attribution NonCommercial License (https:///creativecommons.org/licenses/by-nc/4.0/) which permits unrestricted noncommercial use, distribution, and reproduction in any medium, provided the original work is properly cited. have been carrying out enterprise credit certification and credit rating. Scholars have also begun to pay attention to the impact of corporate integrity on corporate behavior.

Integrity is an important social capital aside from the human capital and material capital for enterprises. Integrity can influence the behavior of managers and employees imperceptibly through codes of conduct and ethical standards (Putnam, 1993). Advocating integrity is signaling to the outside the firm's high-quality image (Murphy, 1998). Under asymmetric information, integrity enterprises can win market recognition and obtain more commercial credit (Zhai, Li, \& Xu, 2015). Integrity enterprises conduct less earnings management (Jiang, Shi, \& Li, 2015). The information disclosure of integrity enterprises is likely to be timely and accurate, with negative news fully released and market liquidity risk reduced. Thus, the stock price crash risk of integrity firms is probably lower than that of nonintegrity firms.

This paper uses a sample of 1419 firms listed in Shenzhen Stock Exchange in China during the period of 2004-2017 and empirically tests the impact of corporate integrity on stock price crash risk. Results show that 
corporate integrity is negatively correlated with stock price crash risk. After changing the selection of samples, model estimation methods and the proxy variable of dependent variables, the conclusion is still valid. Further research finds that the negative correlation between corporate integrity and stock price crash risk only exists in firms with weak overall internal control and located in areas where legal system lags behind. This means that business ethics, such as integrity, can make up for the deficiency of formal systems, inhibit the opportunistic behavior of the management, and compress the capacity for the management to conceal bad news. Finally, the timely release of bad news can help improve the market pricing efficiency.

This research may contribute in the following aspects:

First, this research enhances the understanding of influencing factors of stock price crash risk. In recent years, the influencing factors of stock price crash risk have become a hot topic in accounting field. Prior research provides evidence of a link between stock price crash risk and corporate governance (Kothari, Shu, \& Wysocki, 2009; Kim, Li, \& Zhang, 2011; Piotroski, Wong, \& Zhang, 2015), information disclosure (Hutton, Marcus, \& Tehranian, 2009; Kim \& Zhang, 2012), and institutional environment (Kim, Li, Lu, \& Yu, 2016; Tian \& Wang, 2017). No prior study examines the potential of business ethics in preventing stock price crash. This paper adds to the literature by exploring whether corporate integrity can help prevent stock price crash.

Second, this paper provides new empirical evidence of the influence of business ethics on corporate behavior. Business ethics requires that business entities should not damage the interests of stakeholders in pursuit of their own interests. Corporate integrity is the embodiment of business ethics in corporate governance. Previous studies have mainly focused on the dishonest corporate behaviors such as "tunneling" of controlling shareholders (Bertrand, \& Mullainathan, 2002; Bae, Kang \& Kim, 2002; Joh, 2003) and its consequences (Johnson, Porta, \& Shleifer, 2000; Wurgler, 2000). This paper investigates the determinant of corporate stock price crash risk from the perspective of corporate integrity, enriching the literature in business ethics.

Third, this paper investigates the impact of business ethics on corporate stock price crash risk in an emerging market, which has certain practical application value for managers, investors and regulators. For managers, the construction of integrity culture can help to alleviate the principal-agent problem, reduce financing costs and reduce stock mispricing. For investors, under uncertain environment, conducting transactions with integrity firms can help to reduce transaction cost and improve transaction efficiency. For regulators, strengthening the construction of credit system helps to improve disclosure environment and resource allocation efficiency. Especially for the emerging markets whose legal systems are immature, corporate integrity can make up for the imperfect legal system and promote the optimal allocation of resources.

\section{Literature Review and Theoretical Analysis}

Stock price crash refers to the sudden sharp drop of stock price under unexpected circumstances. Stock price crash not only damages the wealth of investors, but also disrupts the long-term development of the capital market. There are multiple reasons for stock price crash, from corporate governance and information disclosure to institutional environment. Good corporate governance helps to alleviate agency problems (Shleifer \& Vishny, 1997), inhibit opportunistic behavior of management and tunneling of large shareholders, and reduce negative news, thus reducing the risk of stock price crash (An \& Zhang, 2013). Stock price crash originates from the hiding of bad news by management. Once the accumulated bad news breaks through the threshold and is perceived by the market, it will cause the stock price to fall until the crash happens (Jin \& Myers, 2006). Full and timely information disclosure can help release bad news and reduce the risk of stock price crash. Therefore, the higher the quality of information disclosure, the lower the probability of stock price crash (Song, 2015). The stock price crash risk is also affected by capital market participants such as analysts. Analysts' overoptimism may cover the impact of bad news and exacerbate stock price crash risk (Xu, Jiang, Chan, \& Yi, 2013).

Reviewing the previous literature, it can be found that although some achievements have been made in the field of stock price crash risk, few, if any, researches have been conducted from the perspective of business ethics. As part of business ethics, corporate integrity may restrain stock price crash risk in the following two ways:

First, corporate integrity may reduce stock price crash risk by influencing the behavior of managers. Social control theory holds that society or organization can regulate their members' behaviors through "hard control" such as regime and law, or through "soft control" such as morality, custom, public opinion and social psychology, in order to prevent unfavorable behaviors to society (Ross, 1901). Culture is a way of social control in an organization (O'Reilly \& Chatman, 1996). Firms with an integrity culture will discourage the selfish opportunistic behavior of management. Employees who abide by the principle of integrity will form a kind of supervision over management. Once the management violates the principle of integrity, it will be rejected and even kicked out (Elster, 1989). Therefore, enterprises with integrity always have lower 
earnings management (Jiang, 2018) and lower agency costs. The lower level of earnings management means higher quality disclosure (Bhattacharya, Daouk, \& Welker, 2003). Higher quality disclosure means that bad news can be recognized and issued timely and accurately. Once the negative news is incorporated into the stock price in time, the market pricing efficiency is greatly improved, and stock price crash risk is reduced (Grullon, Michenaud, \& Weston, 2015). In a word, corporate integrity may reduce stock price crash risk by decreasing earnings management and improving the quality of information disclosure.

Second, corporate integrity may reduce stock price crash risk by influencing the perception of investors. Psychology and behavioral finance hold that investors are not entirely rational (De Long, Shleifer, Summers, \& Waldmann, 1990; Barberis \& Thaler, 2003). In terms of information acquisition and storage, the individual's original knowledge, experience and emotion can affect his selective attention to information (Plous, 1993). In the context of high uncertainty and high ambiguity, investors tend to choose their trusted partners to trade. The formation of trust is a long-term process (Brockner et al., 1997). Investors will judge whether a company is credible according to the "rule of thumb" and then make investment decisions. They tend to focus on the past and even ignore the underlying value of the company (Stout, 2002). Enterprises with integrity have trustworthy images, which have a certain impact on investors' perceptions. In the context of limited rationality, investors may prefer to choose to invest in firms they trust (Sapienza \& Zingales, 2012). Therefore, corporate integrity may reduce the risk of stock price crash by changing investors' perceptions. Based on the above analysis, the following assumption is proposed:

H1: As compared to firms without integrity, firms with integrity probably have significantly lower stock price crash risk.

\section{Methodology}

\subsection{Sample Selection and Data Source}

This research takes A-share listed firms in Shenzhen Stock Exchange during the period of 2004-2017 as a sample. The initial research samples were screened as follows: (1) Excluding the sample of financial and insurance industries; (2) Excluding the sample of insolvent companies; (3) Excluding ST samples; (4) Excluding samples with less than 30 annual trading weeks; (5) Excluding samples from less than 5 firms in the industry; (6) Excluding firms with missing data. The final firm-year observation was 7552. The main variable (corporate integrity) was hand collected on the official website of
Shenzhen Stock Exchange and from CSMAR database. The internal control data comes from the internal control index issued by Dibo Big Data Research Center. The legal system environmental data comes from China's provincial marketization index compiled by Fan et al. (2011) and Wang et al. (2017). The stock return data and financial data are from CSMAR database. In order to avoid potential outliers, main continuous variables are tailed at $1 \%$ level.

\subsection{Definition of Variables}

\subsubsection{Corporate Integrity}

Corporate integrity is an abstract concept, including accounting integrity, tax integrity, and cultural integrity. Drawing on Wang (2014), this paper constructs a comprehensive index as a proxy variable for corporate integrity from four aspects: whether the firm is sued, whether the firm is punished by authorities, whether senior executives of the firm are publicly condemned, and whether the firm discloses high quality accounting information. The data of "whether the firm is sued" comes from CSMAR database. It will take 1 if the sample firm has been sued or 0 otherwise. The data of "whether the firm is punished by authorities" and "whether senior executives of the firm are publicly condemned" are hand collected from Shenzhen Stock Exchange website. As the data of "whether the firm is punished by authorities" and "whether senior executives of the firm are publicly condemned" are mixed, the two are not distinguished and are taken as one proxy variable.

It will take 1 if the firm has been punished or the executives have been condemned or 0 otherwise. The quality of information disclosure reflects the accounting integrity of the firm. The data of the quality of information disclosure is hand collected from Shenzhen Stock Exchange website. The information disclosure of listed firms is classified into four categories: excellent, good, qualified and unqualified or A, B, C and D, respectively. "Excellent", "good", "qualified" and "unqualified" are assigned 0,1,2,3 respectively. Adding the above three factors can get a comprehensive index of corporate integrity. The value of this index ranges from 0 to 5 . The smaller the value, the more integrity the firm has.

\subsubsection{Stock Price Crash Risk}

Drawing on Hutton et al. (2009) and Kim et al. (2011), this research uses the following two methods to measure stock price crash risk:

First, we calculate the market-adjusted stock return by model (1).

$$
\begin{aligned}
& r_{i, t}=\alpha+\beta_{1, i} r_{m, t-2}+\beta_{2, i} r_{m, t-1}+\beta_{3, i} r_{m, t}+ \\
& \beta_{4, \mathrm{i}} r_{m, t+1}+\beta_{5, i} r_{m, t+2}+\varepsilon_{i, t}
\end{aligned}
$$


Among them, $r_{i, t}$ is the weekly return of stock $i$, which considers the reinvestment of cash dividends in week $t . r_{m, t}$ is the market return in week $t$ weighted by the circulating market value. $\varepsilon_{\mathrm{i}, \mathrm{t}}$ is the regression residual, which represents the part of the weekly return of stock i not explained by the market weekly return. The logarithmic transformation of the residual term is carried out as follows, and the weekly specific return of stock $i$ in week $t$ is obtained.

$$
\mathrm{W}_{\mathrm{i}, \mathrm{t}}=\ln \left(1+\varepsilon_{\mathrm{i}, \mathrm{t}}\right)
$$

Table 1: Definitions and Measurement of Variables

\begin{tabular}{|c|c|c|}
\hline Type & Sign & Definitions \\
\hline \multirow[t]{2}{*}{$\begin{array}{l}\text { Dependent } \\
\text { Variable }\end{array}$} & NCSKEW & $\begin{array}{l}\text { Negative return skewness } \\
\text { coefficient. The calculation } \\
\text { process is shown in Model (3). } \\
\text { The greater the value, the greater } \\
\text { the risk of stock price crash. }\end{array}$ \\
\hline & CRASH & $\begin{array}{l}\text { Dummy variable of stock price } \\
\text { crash risk, calculated as Model } \\
\text { (4) }\end{array}$ \\
\hline $\begin{array}{l}\text { Independent } \\
\text { Variable }\end{array}$ & Integrity & $\begin{array}{l}\text { Corporate integrity level, } \\
\text { including whether the firm is } \\
\text { sued, whether the firm is } \\
\text { punished by regulators, whether } \\
\text { the executives are publicly } \\
\text { condemned and whether the firm } \\
\text { discloses high quality accounting } \\
\text { information. The value of the } \\
\text { index ranges between } 0-5 \text {. The } \\
\text { higher the value of this index, the } \\
\text { less integrity the firm is. }\end{array}$ \\
\hline \multirow[b]{2}{*}{$\begin{array}{l}\text { Moderating } \\
\text { variables }\end{array}$} & $\begin{array}{l}\text { Internal } \\
\text { Control }\end{array}$ & $\begin{array}{l}\text { Internal control level, Dibo } \\
\text { Internal Control Index }\end{array}$ \\
\hline & Law & $\begin{array}{l}\text { The legal system environment, } \\
\text { the Development of } \\
\text { Intermediaries and the Level of } \\
\text { Legal System Environment index } \\
\text { of the provinces where the firm is } \\
\text { registered. }\end{array}$ \\
\hline \multirow{8}{*}{$\begin{array}{c}\text { Control } \\
\text { variables }\end{array}$} & Size & $\begin{array}{l}\text { Firm size, the natural logarithm } \\
\text { of the ending total assets. }\end{array}$ \\
\hline & Lev & $\begin{array}{l}\text { debt level, total liabilities /total } \\
\text { assets }\end{array}$ \\
\hline & ROA & $\begin{array}{l}\text { Profitability, net profit/average } \\
\text { total assets }\end{array}$ \\
\hline & MB & Market-to-book ratio \\
\hline & RET & $\begin{array}{l}\text { The mean of the weekly specific } \\
\text { return of the stock }\end{array}$ \\
\hline & SIGMA & $\begin{array}{l}\text { The standard deviation of the } \\
\text { weekly specific return of the } \\
\text { stock }\end{array}$ \\
\hline & Oturnover & The change of stock turnover rate \\
\hline & Opaque & $\begin{array}{l}\text { Information transparency, the } \\
\text { average of the discretionary } \\
\text { accruals of the previous three } \\
\text { years, discretionary accruals is } \\
\text { calculated according to modified } \\
\text { Jones model. }\end{array}$ \\
\hline
\end{tabular}

On the basis of $\mathrm{W}_{\mathrm{i}, \mathrm{t}}$, we use the following method to construct the first index NCSKEW to measure of stock price crash risk:

$$
\begin{aligned}
& \operatorname{NCSKEW}_{\mathrm{i}, \mathrm{t}}=-\left[\mathrm{n}(\mathrm{n}-1)^{\frac{3}{2}} \sum \mathrm{W}_{\mathrm{i}, \mathrm{t}}{ }^{3}\right] /[(\mathrm{n}-1)(\mathrm{n}- \\
& \left.2)\left(\sum \mathrm{W}_{\mathrm{i}, \mathrm{t}}{ }^{2}\right)^{\frac{3}{2}}\right]
\end{aligned}
$$

Then, we construct the dummy variable of stock price crash risk CRASH. If the weekly specific return of stock i satisfies the following conditions at least once in a year, it means that stock price crash occurred in that year. CRASH takes 1 if stock price crash occurs or 0 otherwise.

$$
\mathrm{W}_{\mathrm{i}, \mathrm{t}} \leq \text { Average }\left(\mathrm{W}_{\mathrm{i}, \mathrm{t}}\right)-3.09 \sigma_{\mathrm{i}, \mathrm{t}}
$$

\subsubsection{Moderating Variables}

The moderating variables in this research are corporate internal control and legal system environment of the provinces where the firm operates. We use Dibo internal control index as a proxy variable for corporate internal control. The higher the internal control index is, the better corporate internal control is. Drawing on existing literature, we measure legal system environment by the Development of Intermediaries and the Level of Legal System Environment Index compiled by Fan, Wang and Zhu (2011), Wang, Fan and $\mathrm{Yu}$ (2017). The higher the index, the better the legal system environment is.

\subsubsection{Control Variables}

According to the existing literature, this study controls the possible impact of the following variables: one-period lag negative return skewness coefficient, firm size, debt level, profitability, market-to-book ratio, annual specific return, standard deviation of specific return, excess turnover rate, information transparency. In addition, year and industry dummy variables are introduced to control year and industry fixed effects. The specific definition of variables is shown in Table 1.

\subsection{Model design}

To test the above hypothesis, the following models are constructed:

$$
\begin{aligned}
\text { NCSKEW }_{\mathrm{t}}=\beta_{0} & +\beta_{1} \text { Sincerity }_{\mathrm{t}-1}+\beta_{2} \text { NCSKEW }_{\mathrm{t}-1} \\
& +\beta_{3} \text { Size }_{\mathrm{t}-1}+\beta_{4} \text { Lev }_{\mathrm{t}-1}+\beta_{5} \text { ROA }_{\mathrm{t}-1} \\
& +\beta_{6} \text { MB }_{\mathrm{t}-1}+\beta_{7} \text { RET }_{\mathrm{t}-1}+\beta_{8} \text { SIGMA }_{\mathrm{t}-1} \\
& +\beta_{9} \text { Oturnover }_{\mathrm{t}-1}+\beta_{10} \text { Opaque }_{\mathrm{t}-1} \\
& +\sum \text { Year }+\sum{\text { Industry }+\varepsilon_{\mathrm{i}, \mathrm{t}}}
\end{aligned}
$$




$$
\begin{aligned}
\text { CRASH }_{\mathrm{t}}=\beta_{0}+ & \beta_{1} \text { Sincerity }_{\mathrm{t}-1}+\beta_{2} \text { NCSKEW }_{\mathrm{t}-1} \\
& +\beta_{3} \text { Size }_{\mathrm{t}-1}+\beta_{4} \text { Lev }_{\mathrm{t}-1}+\beta_{5} \mathrm{ROA}_{\mathrm{t}-1} \\
& +\beta_{6} \mathrm{MB}_{\mathrm{t}-1}+\beta_{7} \text { RET T }_{\mathrm{t}-1}+\beta_{8} \text { SIGMA }_{\mathrm{t}-1} \\
& +\beta_{9} \text { Oturnover }_{\mathrm{t}-1}+\beta_{10} \text { Opaque }_{\mathrm{t}-1} \\
& +\sum \text { Year }+\sum \text { Industry } \varepsilon_{\mathrm{i}, \mathrm{t}}
\end{aligned}
$$

Model (5) adopts OLS regression and model (6) adopts Logistic regression. In order to test the moderating effect of internal control and legal system environment on the relationship between corporate integrity and stock price crash risk, the samples are divided into groups according to the internal control and legal system environment and then test whether significant differences exist in the coefficients between groups.

\section{Results and Discussion}

\subsection{Descriptive Statistics}

Descriptive statistics of major variables are shown in Table 2. The mean and standard deviation of NCSKEW are -0.233 and 0.626 respectively, which indicates that great differences exist in stock price crash risk among sample firms. The mean value of CRASH is 0.091, which indicates that $9.1 \%$ of the sample firms has undergone stock price crash risk, which is lower than the U.S. listed firms, approximately $16 \%$ (Kim et al., 2011). The mean and median of Integrity are 1.097 and 1.000 respectively, which indicates that more or less deficiencies exist in corporate integrity in Chinese firms. Corporate integrity needs to be further improved.

In order to compare the differences between firms with integrity and firms without integrity, we divide the sample firms into three groups. If the value of integrity of the firm takes 0 , it is partitioned into high-integrity group. If the value of integrity of the firm takes 1 , it is partitioned into medium-integrity group. If the value of the integrity of the firm takes $2,3,4,5$, it is partitioned into low-integrity group. The focus of this research is the differences between highand low-integrity groups. The grouping statistics by means are shown in Table 3. The mean value of NCSKEW in high-integrity group is -0.2498 , which is smaller than that in low-integrity group at the significance level of $1 \%$. This means that stock price crash risk of high-integrity firms is significantly smaller than that of low-integrity firms. The mean value of CRASH in high-integrity group is 0.0822 , which is smaller than that in low-integrity group at the 5\% significance level, supporting the above hypothesis H1. The mean values of Size, ROA, MB and RET in high-integrity group are significantly larger than those in low-integrity group, and the mean values of Lev, SIGMA, Oturnover and Opaque in high-integrity group are significantly smaller than those in low-integrity group. This indicates that as compared to low-integrity firms, high-integrity firms tend to be firms with larger size, less debt, stronger profitability, fewer risks, and more transparent disclosure.

\subsection{Multivariate Regression Results}

Table 2: Descriptive Statistics

\begin{tabular}{|c|c|c|c|c|c|c|}
\hline Variable & $\mathbf{N}$ & Mean & S.D. & Min & Median & Max \\
\hline NCSKEW $_{\mathrm{t}}$ & 7552 & -0.233 & 0.626 & -1.992 & -0.200 & 1.401 \\
\hline CRASH $_{\mathrm{t}}$ & 7552 & 0.091 & 0.287 & 0.000 & 0.000 & 1.000 \\
\hline Sincerity $_{\mathrm{t}-1}$ & 7552 & 1.097 & 0.764 & 0.000 & 1.000 & 5.000 \\
\hline NCSKEW $_{\mathrm{t}-1}$ & 7552 & -0.223 & 0.620 & -1.992 & -0.196 & 1.382 \\
\hline Size $_{\mathrm{t}-1}$ & 7552 & 21.927 & 1.071 & 19.298 & 21.820 & 24.907 \\
\hline Lev $_{\mathrm{t}-1}$ & 7552 & 0.453 & 0.197 & 0.043 & 0.456 & 0.862 \\
\hline ROA $_{\mathrm{t}-1}$ & 7552 & 0.040 & 0.056 & -0.158 & 0.035 & 0.216 \\
\hline MB $_{\mathrm{t}-1}$ & 7552 & 2.497 & 1.725 & 0.920 & 1.930 & 11.154 \\
\hline RET $_{\mathrm{t}-1}$ & 7552 & -0.001 & 0.001 & -0.006 & -0.001 & 0.000 \\
\hline SIGMA $_{\mathrm{t}-1}$ & 7552 & 0.048 & 0.018 & 0.018 & 0.045 & 0.107 \\
\hline Oturnover $_{\mathrm{t}-1}$ & 7552 & -0.631 & 36.138 & -184.271 & 0.524 & 97.240 \\
\hline Opaque $_{\mathrm{t}-1}$ & 7552 & 0.063 & 0.049 & 0.008 & 0.050 & 0.281 \\
\hline
\end{tabular}

Table 3: Grouping Statistics by Means

\begin{tabular}{|c|c|c|c|}
\hline & $\begin{array}{c}\text { High- } \\
\text { Integrity }\end{array}$ & $\begin{array}{c}\text { Low- } \\
\text { Integrity }\end{array}$ & $\begin{array}{c}\text { Diff. } \\
\text { (t-value })\end{array}$ \\
\hline NCSKEW $_{\mathrm{t}}$ & -0.2498 & -0.1774 & $\begin{array}{c}-0.0724^{* * *} \\
(-3.165)\end{array}$ \\
\hline CRASH $_{\mathrm{t}}$ & 0.0822 & 0.1050 & $\begin{array}{c}-0.0228^{* *} \\
(-2.137)\end{array}$ \\
\hline Size $_{\mathrm{t}-1}$ & 22.4361 & 21.6506 & $\begin{array}{c}0.7855^{* * *} \\
(19.798)\end{array}$ \\
\hline Lev $_{\mathrm{t}-1}$ & 0.4099 & 0.4929 & $\begin{array}{c}-0.0830^{* * *} \\
(-11.619)\end{array}$ \\
\hline ROA $_{\mathrm{t}-1}$ & 0.0728 & 0.0157 & $\begin{array}{c}0.0571^{* * *} \\
(27.554)\end{array}$ \\
\hline MB $_{\mathrm{t}-1}$ & 2.7179 & 2.4476 & $\begin{array}{c}0.2703^{* * *} \\
(4.079)\end{array}$ \\
\hline RET $_{\mathrm{t}-1}$ & -0.0012 & -0.0014 & $\begin{array}{c}0.0002^{* * *} \\
(6.212)\end{array}$ \\
\hline SIGMA $_{\mathrm{t}-1}$ & 0.0456 & 0.0503 & $\begin{array}{c}-0.0047^{* * *} \\
(-7.031)\end{array}$ \\
\hline Oturnover $_{\mathrm{t}-1}$ & -1.9105 & 0.9093 & $\begin{array}{c}-2.8198^{* *} \\
(-2.1685)\end{array}$ \\
\hline Opaque $_{\mathrm{t}-1}$ & 0.0604 & 0.0652 & $\begin{array}{c}-0.0048^{* * *} \\
(-2.707)\end{array}$ \\
\hline
\end{tabular}

Note: ${ }^{*}, * * * *$ represent significance levels of $10 \%, 5 \%, 1 \%$ respectively. 
Table 4 reports the results of multivariate regression of model (5) and model (6). Columns (1) and (2) are OLS regression results with NCSKEW as a dependent variable. The coefficient of Integrity is 0.023 when no control variables are added, which is significant at the level of 5\%. After controlling other variables, the sign of the coefficient of Integrity is still positive, but the significance level decreases. Columns (3) and (4) are Logistic regression results with $\mathrm{CRASH}$ as a dependent variable. In both models, the coefficients of Integrity are significantly positive at the level of $5 \%$. As the value of the Integrity index means the dishonest level of the firm, the positive regression coefficient means that corporate integrity is negatively correlated with stock price crash risk, which is consistent with the above hypothesis $\mathrm{H} 1$.

Table 4: Corporate Integrity and Stock Price Crash Risk

\begin{tabular}{|c|c|c|c|c|}
\hline & \multicolumn{2}{|c|}{ NCSKEW } & \multicolumn{2}{|c|}{ CRASH } \\
\hline \multirow[t]{2}{*}{ Integrity $_{\mathrm{t}-1}$} & $0.023 * *$ & $0.018^{*}$ & $0.118^{* *}$ & $0.126^{* *}$ \\
\hline & $(-2.471)$ & $(-1.790)$ & $(-2.261)$ & $(-2.262)$ \\
\hline \multirow[t]{2}{*}{ NCSKEW $_{\mathrm{t}-1}$} & & $0.031 * * *$ & & 0.021 \\
\hline & & $(-2.636)$ & & $(-0.306)$ \\
\hline \multirow[t]{2}{*}{ Size $_{t-1}$} & & $-0.024 * * *$ & & -0.039 \\
\hline & & $(-2.586)$ & & $(-0.710)$ \\
\hline \multirow[t]{2}{*}{$\operatorname{Lev}_{\mathrm{t}-1}$} & & 0.035 & & 0.376 \\
\hline & & $(-0.707)$ & & $(-1.305)$ \\
\hline \multirow[t]{2}{*}{$\mathrm{ROA}_{\mathrm{t}-1}$} & & $0.391 * *$ & & 0.925 \\
\hline & & $(-2.496)$ & & $(-1.021)$ \\
\hline \multirow[t]{2}{*}{$\mathrm{MB}_{\mathrm{t}-1}$} & & $0.025 * * *$ & & $0.059^{*}$ \\
\hline & & $(-4.082)$ & & $(-1.752)$ \\
\hline \multirow[t]{2}{*}{$\mathrm{RET}_{\mathrm{t}-1}$} & & $97.652 * * *$ & & -189.542 \\
\hline & & $(-2.995)$ & & $(-0.962)$ \\
\hline \multirow[t]{2}{*}{ SIGMA $_{\mathrm{t}-1}$} & & $7.180 * * *$ & & -13.532 \\
\hline & & $(-3.744)$ & & $(-1.209)$ \\
\hline \multirow[t]{2}{*}{ Oturnover $_{\mathrm{t}-1}$} & & 0.000 & & -0.002 \\
\hline & & $(-0.056)$ & & $(-1.197)$ \\
\hline \multirow[t]{2}{*}{ Opaque $_{t-1}$} & & 0.198 & & 0.360 \\
\hline & & $(-1.245)$ & & $(-0.387)$ \\
\hline \multirow[t]{2}{*}{ constant } & -0.008 & 0.259 & $-1.326^{* * *}$ & -0.537 \\
\hline & $(-0.119)$ & $(-1.209)$ & $(-4.013)$ & $(-0.430)$ \\
\hline YEAR & Yes & Yes & Yes & Yes \\
\hline INDUSTRY & Yes & Yes & Yes & Yes \\
\hline $\mathrm{N}$ & 7552 & 7552 & 7552 & 7552 \\
\hline $\begin{array}{c}\text { Adj-R }{ }^{2} / \\
\text { Pseudo } R^{2}\end{array}$ & 0.054 & 0.067 & 0.052 & 0.062 \\
\hline $\begin{array}{c}\text { F-value / } \\
\text { Chi-square }\end{array}$ & 14.87 & 14.47 & 96.78 & 167.31 \\
\hline
\end{tabular}

\subsection{Robust test}

In order to enhance the reliability of the findings, we conduct the following robust tests: (1) Change the sample selection method. Some listed firms have been mandated to issue social responsibility reports since 2008 , which may have some impact on stock price crash risk (Tian \& Wan, 2011).

Table 5: Robust Test

\begin{tabular}{|c|c|c|c|c|}
\hline & NCSKEW & CRASH & $\begin{array}{c}\text { Fixed E } \\
\text { ffect }\end{array}$ & DUVOL \\
\hline \multirow[t]{2}{*}{ Integrity $_{\mathrm{t}-1}$} & $0.020 *$ & $0.146^{* *}$ & $0.027 * *$ & $0.020 * *$ \\
\hline & $(-1.698)$ & $(-2.165)$ & $(-2.138)$ & $(-2.215)$ \\
\hline \multirow{2}{*}{ NCSKEW $_{\mathrm{t}-1}$} & $0.041 * * *$ & 0.082 & $-0.140 * * *$ & $-0.090 * * *$ \\
\hline & $(-3.046)$ & $(-1.075)$ & $(-10.912)$ & $(-9.642)$ \\
\hline \multirow[t]{2}{*}{ Size $_{t-1}$} & $-0.032 * * *$ & -0.084 & 0.015 & 0.002 \\
\hline & $(-2.909)$ & $(-1.312)$ & $(-0.644)$ & $(-0.099)$ \\
\hline \multirow[t]{2}{*}{$\mathrm{Lev}_{\mathrm{t}-1}$} & 0.044 & 0.452 & -0.061 & -0.034 \\
\hline & $(-0.794)$ & $(-1.446)$ & $(-0.689)$ & $(-0.538)$ \\
\hline \multirow[t]{2}{*}{$\mathrm{ROA}_{\mathrm{t}-1}$} & $0.560 * * *$ & $2.091 * *$ & 0.225 & 0.187 \\
\hline & $(-3.223)$ & $(-2.013)$ & $(-1.091)$ & $(-1.251)$ \\
\hline \multirow[t]{2}{*}{$\mathrm{MB}_{\mathrm{t}-1}$} & $0.016^{* *}$ & 0.020 & $0.054 * * *$ & $0.036^{* * *}$ \\
\hline & $(-2.404)$ & $(-0.541)$ & $(-5.977)$ & $(-5.532)$ \\
\hline \multirow[t]{2}{*}{$\mathrm{RET}_{\mathrm{t}-1}$} & $113.992 * * *$ & -262.691 & $63.010^{*}$ & $50.481 *$ \\
\hline & $(-3.040)$ & $(-1.171)$ & $(-1.717)$ & $(-1.898)$ \\
\hline \multirow[t]{2}{*}{ SIGMA $_{t-1}$} & $8.236 * * *$ & -16.62 & $5.259 * *$ & $3.875^{* *}$ \\
\hline & $(-3.700)$ & $(-1.262)$ & $(-2.441)$ & $(-2.481)$ \\
\hline \multirow[t]{2}{*}{ Oturnover $_{t-1}$} & 0.000 & -0.002 & 0.000 & 0.000 \\
\hline & $(-0.339)$ & $(-1.060)$ & $(-0.435)$ & $(-0.122)$ \\
\hline \multirow[t]{2}{*}{ Opaque $_{t-1}$} & 0.257 & 0.792 & 0.180 & 0.164 \\
\hline & $(-1.425)$ & $(-0.822)$ & $(-0.831)$ & $(-1.046)$ \\
\hline \multirow[t]{2}{*}{ constant } & -0.131 & -1.967 & -0.720 & -0.311 \\
\hline & $(-0.501)$ & $(-1.280)$ & $(-1.410)$ & $(-0.841)$ \\
\hline YEAR & Yes & Yes & Yes & Yes \\
\hline INDUSTRY & Yes & Yes & Yes & Yes \\
\hline $\mathrm{N}$ & 5969 & 5969 & 7552 & 7552 \\
\hline $\begin{array}{c}\text { Adj-R }{ }^{2} / \\
\text { Pseudo } R^{2}\end{array}$ & 0.061 & 0.039 & 0.033 & 0.039 \\
\hline $\begin{array}{l}\text { F-value/ } \\
\text { Chi-square }\end{array}$ & 12.17 & 132.40 & 16.37 & 16.03 \\
\hline
\end{tabular}

Therefore, we delete the observations before 2008. The results are shown in columns (1) and (2) of Table 5. The coefficients of Integrity are significantly positive at the levels of $10 \%$ and $5 \%$, respectively, which are consistent with the results of the main regression. (2) Change the model estimation method. We replace OLS regression with a fixed effect model panel regression on model (5). The 
result is shown in column (3) of table 5. The coefficient of Integrity is 0.027 , which is significant at the level of 5\%. (3) Change the measurement of dependent variables. Drawing on previous literature, we use DUVOL as an alternative proxy for stock price crash risk. First, we divide stock returns into two stages, i.e. Up and Down, according to whether the firm's specific weekly return $\mathrm{W}_{\mathrm{i}}$ is greater than the annual average return. Then we calculate the standard deviations of stock returns in the two stages separately, i.e. $\mathrm{Ru}$ and $\mathrm{Rd}$. Finally, we use the following formula to obtain DUVOL:

$\operatorname{DUVOL}_{\mathrm{i}, \mathrm{t}}=\ln \left\{\left[\left(\mathrm{n}_{\mathrm{u}}-1\right) \sum_{\text {Down }} \mathrm{R}_{\mathrm{d}}^{2}\right] /\left[\left(\mathrm{n}_{\mathrm{d}}-1\right) \sum_{\mathrm{Up}} \mathrm{R}_{\mathrm{u}}^{2}\right]\right\}$

The result is shown in column (4) of table 5. The sign of the coefficient of Integrity is positive, significant at the level of 5\%, which is consistent with the hypothesis.

\subsection{Further Discussion}

Internal control decreases earnings management and improves the quality of information disclosure (Chan, Farrell, \& Lee, 2008). Better internal control brings about more conservative accounting information (Mitra, Jaggi, \& Hossain, 2013), lower likelihood of management hiding bad news, and lower stock price crash risks (Hammersley, Linda, Myers, \& Catherine, 2008). If a firm's overall internal control is weak, it always means that "hard control", such as rules and regulations, fails to play a full role. Then the role of "soft control", such as corporate integrity, may become more prominent.

In order to test whether internal control exerts impacts on the relationship between corporate integrity and stock price crash risk, the sample firms are divided into two groups according to the level of internal control. If the firm's internal control index exceeds the year/industry median, it is grouped into Good Internal Control; otherwise, it is Poor Internal Control. The regression results are shown in Table 6. From Table 6, we can see that the coefficient of Integrity is significantly positive in the group with poor internal control, but not significant in the group with good internal control. It shows that integrity, as business ethics, can compensate for the "hard control" of the corporations and restrain stock price crash risk.

The more perfect the legal system and the stronger the protection of investors, the more transparency the corporate information (Bushman, Piotroski, \& Smith, 2004), the higher the content of stock price information (Morck, Yeung, \& Yu, 2000), the lower the possibility of hiding bad news through opportunistic behavior, and the lower the risk of stock price crash. In the relatively poor institutional environment, failure to observe the law and weak law enforcement often occur. The lagging supervision makes corporate integrity more prominent in corporate governance.

In order to test whether the legal system environment has an impact on the relationship between corporate integrity and stock price crash risk, we divide the sample firms into two groups in accordance with the legal system environment where the firm is registered. If the Development of Intermediaries and the Level of Legal System Environment index of the province where the firm is registered exceeds the median, it is Good Legal Environment; otherwise, it is Poor Legal Environment.

Table 6: Corporate Integrity, Internal Control and Stock Price Cra sh Risk

\begin{tabular}{|c|c|c|c|c|}
\hline & \multicolumn{2}{|c|}{ NCSKEW } & \multicolumn{2}{|c|}{ CRASH } \\
\hline & $\begin{array}{c}\text { Good } \\
\text { Internal } \\
\text { Control }\end{array}$ & $\begin{array}{c}\text { Poor } \\
\text { Internal } \\
\text { Control }\end{array}$ & $\begin{array}{c}\text { Good } \\
\text { Internal } \\
\text { Control }\end{array}$ & $\begin{array}{c}\text { Poor } \\
\text { Internal } \\
\text { Control } \\
\end{array}$ \\
\hline \multirow[t]{2}{*}{ Integrity $_{t-1}$} & -0.012 & $0.038 * * *$ & 0.103 & $0.173^{* *}$ \\
\hline & $(-0.750)$ & $(-2.919)$ & $(-1.117)$ & $(-2.371)$ \\
\hline \multirow[t]{2}{*}{ NCSKEW $_{t-1}$} & 0.026 & $0.029 *$ & 0.000 & 0.022 \\
\hline & $(-1.529)$ & $(-1.778)$ & $(-0.004)$ & $(-0.226)$ \\
\hline \multirow{2}{*}{ Size $_{t-1}$} & $-0.042 * * *$ & -0.021 & $-0.154 * *$ & 0.046 \\
\hline & $(-3.189)$ & $(-1.426)$ & $(-2.048)$ & $(-0.507)$ \\
\hline \multirow[t]{2}{*}{$\operatorname{Lev}_{t-1}$} & 0.004 & 0.058 & 0.219 & 0.455 \\
\hline & $(-0.059)$ & $(-0.874)$ & $(-0.512)$ & $(-1.135)$ \\
\hline \multirow[t]{2}{*}{$\mathrm{ROA}_{\mathrm{t}-1}$} & $0.567 * *$ & 0.119 & -0.249 & 0.576 \\
\hline & $(-2.103)$ & $(-0.562)$ & $(-0.165)$ & $(-0.454)$ \\
\hline \multirow[t]{2}{*}{$\mathrm{MB}_{\mathrm{t}-1}$} & $0.018 * *$ & $0.024 * * *$ & 0.048 & $0.092 *$ \\
\hline & $(-2.054)$ & $(-2.754)$ & $(-0.976)$ & $(-1.820)$ \\
\hline \multirow[t]{2}{*}{$\mathrm{RET}_{\mathrm{t}-1}$} & $125.218^{* * *}$ & $83.572 *$ & -205.232 & -157.249 \\
\hline & $(-2.627)$ & $(-1.845)$ & $(-0.739)$ & $(-0.546)$ \\
\hline \multirow[t]{2}{*}{ SIGMA $_{\mathrm{t}-1}$} & $7.591 * * *$ & $7.576 * * *$ & -19.698 & -8.046 \\
\hline & $(-2.728)$ & $(-2.821)$ & $(-1.254)$ & $(-0.487)$ \\
\hline \multirow[t]{2}{*}{ Oturnover $_{\mathrm{t}-1}$} & 0.000 & 0.000 & 0.002 & $-0.005 * *$ \\
\hline & $(-0.593)$ & $(-0.943)$ & $(-0.892)$ & $(-2.222)$ \\
\hline \multirow[t]{2}{*}{ Opaque $_{t-1}$} & -0.169 & $0.479 * *$ & 0.656 & 0.199 \\
\hline & $(-0.733)$ & $(-2.166)$ & $(-0.508)$ & $(-0.146)$ \\
\hline \multirow[t]{2}{*}{ constant } & $0.689 * *$ & 0.128 & 1.489 & -2.087 \\
\hline & $(-2.281)$ & $(-0.387)$ & $(-0.864)$ & $(-1.038)$ \\
\hline YEAR & Yes & Yes & Yes & Yes \\
\hline INDUSTRY & Yes & Yes & Yes & Yes \\
\hline $\mathrm{N}$ & 3716 & 3836 & 3716 & 3836 \\
\hline $\begin{array}{c}\text { Adj-R }{ }^{2} / \\
\text { Pseudo } R^{2}\end{array}$ & 0.06 & 0.079 & 0.051 & 0.065 \\
\hline $\begin{array}{c}\text { F-value/ } \\
\text { Chi-square }\end{array}$ & 6.916 & 9.193 & 121.59 & 144.09 \\
\hline
\end{tabular}

The regression results are shown in Table 7. It can be seen from the table that in the group with good legal environment, the coefficient of Integrity is not significant. 
While in the group with poor legal environment, it is significantly positive at the level of $5 \%$. It indicates that corporate integrity is a substitute for formal systems in curbing stock price crash risk.

Table 7: Corporate Integrity, legal system environment and Stock Price Crash Risk

\begin{tabular}{|c|c|c|c|c|}
\hline & \multicolumn{2}{|c|}{ NCSKEW } & \multicolumn{2}{|c|}{ CRASH } \\
\hline & $\begin{array}{c}\text { Good } \\
\text { Legal } \\
\text { Environ- } \\
\text { ment }\end{array}$ & $\begin{array}{l}\text { Poor Legal } \\
\text { Environ- } \\
\text { ment }\end{array}$ & $\begin{array}{c}\text { Good } \\
\text { Legal } \\
\text { Environ- } \\
\text { ment }\end{array}$ & $\begin{array}{l}\text { Poor Legal } \\
\text { Environ- } \\
\text { ment }\end{array}$ \\
\hline \multirow[t]{2}{*}{ Integrity $_{\mathrm{t}-1}$} & 0.005 & $0.026^{* *}$ & 0.076 & $0.165 * *$ \\
\hline & $(-0.305)$ & $(-2.035)$ & $(-0.802)$ & $(-2.357)$ \\
\hline \multirow{2}{*}{ NCSKEW $_{\mathrm{t}-1}$} & 0.027 & $0.029 *$ & -0.116 & 0.089 \\
\hline & $(-1.448)$ & $(-1.878)$ & $(-1.069)$ & $(-0.992)$ \\
\hline \multirow[t]{2}{*}{ Size $_{t-1}$} & -0.017 & $-0.029 * *$ & 0.061 & -0.103 \\
\hline & $(-1.139)$ & $(-2.415)$ & $(-0.682)$ & $(-1.422)$ \\
\hline \multirow[t]{2}{*}{$\operatorname{Lev}_{\mathrm{t}-1}$} & -0.048 & 0.082 & -0.186 & $0.712 *$ \\
\hline & $(-0.617)$ & -1.243 & $(-0.410)$ & $(-1.851)$ \\
\hline \multirow[t]{2}{*}{$\mathrm{ROA}_{\mathrm{t}-1}$} & $0.523 * *$ & 0.253 & 1.460 & 0.349 \\
\hline & $(-2.104)$ & $(-1.235)$ & $(-1.015)$ & $(-0.293)$ \\
\hline \multirow[t]{2}{*}{$\mathrm{MB}_{\mathrm{t}-1}$} & $0.021 * *$ & $0.027 * * *$ & 0.078 & 0.043 \\
\hline & $(-2.175)$ & $(-3.440)$ & $(-1.468)$ & $(-0.954)$ \\
\hline \multirow[t]{2}{*}{$\operatorname{RET}_{\mathrm{t}-1}$} & 69.599 & $114.226 * * *$ & -237.056 & -178.071 \\
\hline & $(-1.348)$ & $(-2.698)$ & $(-0.783)$ & $(-0.678)$ \\
\hline \multirow[t]{2}{*}{ SIGMA $_{\mathrm{t}-1}$} & $5.955^{* *}$ & $7.711 * * *$ & -18.092 & -12.263 \\
\hline & $(-1.963)$ & $(-3.089)$ & $(-1.042)$ & $(-0.827)$ \\
\hline \multirow[t]{2}{*}{ Oturnover $_{t-1}$} & 0.000 & 0.000 & -0.001 & -0.002 \\
\hline & $(-0.209)$ & $(-0.190)$ & $(-0.398)$ & $(-1.180)$ \\
\hline \multirow[t]{2}{*}{ Opaque $_{t-1}$} & 0.092 & 0.276 & -1.467 & 1.322 \\
\hline & $(-0.346)$ & $(-1.372)$ & $(-0.910)$ & $(-1.144)$ \\
\hline \multirow[t]{2}{*}{ constant } & 0.168 & 0.338 & -2.37 & 0.284 \\
\hline & $(-0.486)$ & $(-1.219)$ & $(-1.185)$ & $(-0.173)$ \\
\hline YEAR & Yes & Yes & Yes & Yes \\
\hline INDUSTRY & Yes & Yes & Yes & Yes \\
\hline $\mathrm{N}$ & 3033 & 4490 & 3033 & 4490 \\
\hline $\begin{array}{c}\text { Adj-R } \mathrm{R}^{2} \\
\text { Pseudo } \mathrm{R}^{2}\end{array}$ & 0.055 & 0.072 & 0.052 & 0.062 \\
\hline $\begin{array}{c}\text { F-value/ } \\
\text { Chi-square }\end{array}$ & 5.41 & 9.70 & 96.78 & 167.31 \\
\hline
\end{tabular}

\section{Conclusions}

This paper takes A-share firms listed in Shenzhen Stock Exchange in China during the period of 2004-2017 as a sample and empirically explores the impact of corporate integrity on stock price crash risk. It is found that corporate integrity affects stock price crash risk by influencing corporate disclosure and managers' behavior. Corporate integrity leads to higher quality of information disclosure, fewer agency conflicts and less possibility of hiding bad news through earnings management, thus decreasing stock price crash risk. Meanwhile, corporate integrity is signaling to the outside world the firm's responsible image. Investors are more inclined to buy stocks which they trust. As such, the stock price crash risk of firms with integrity is lower. Further, research indicates that the relationship between corporate integrity and stock price crash risk only exists in firms with poor internal control and firms in poor legal system environment. It means that corporate integrity can be used as a substitute for formal system to alleviate agency conflicts and reduce stock price crash risk.

This research systematically examines the impact of corporate integrity on stock price crash risk and its mechanism, enriching the literature on the impact of business ethics on corporate behavior. The findings provide some insight for optimizing resource allocation of capital market and preventing financial risks. From the micro perspective, building a corporate culture with integrity can send positive signals to the outside, win the trust of investors and other stakeholders, reduce agency conflicts, and make up for the defects of internal control. Therefore, corporations should build a culture of integrity in order to enhance their competitiveness and sustainable development.

\section{References}

An, H., \& Zhang, T. (2011). Stock price synchronicity, crash risk, and institutional investors. Journal of Corporate Finance, 21(1), 1-15.

Bae, K. H., Kang, J. K., \& Kim, J. M. (2002). Tunneling or value added? evidence from mergers by Korean business groups. Journal of Finance, 57(6), 2695-2740.

Barberis, N., \& Thaler, R. (2003). A survey of behavioral finance. Handbook of the Economics of Finance, 1(03), 1053-1128.

Bertrand, M., \& Mullainathan, M. S. (2002). Ferreting out tunneling: an application to Indian business groups. The Quarterly Journal of Economics, 117(1), 121-148.

Bhattacharya, U., Daouk, H., \& Welker, M. (2003). The world price of earnings opacity. The Accounting Review, 78(3), 641-678.

Brockner, J., Siegel, P. A., Daly, J. P., Tyler, T., \& Martin, C. (1997). When trust matters: the moderating effect of outcome favorability. Administrative Science Quarterly, 42(3), 558.

Bushman, R. M., Piotroski, J. D., \& Smith, A. J. (2004). What determines corporate transparency? Journal of 
Accounting Research, 42(2), 207-252.

Chan, K. C., Farrell, B. R., \& Lee, P. (2008). Earnings management of firms reporting material internal control weaknesses under section 404 of the SarbanesOxley Act. A Journal of Practice \& Theory, 27(2), 161-179.

De Long, J. B., Shleifer, A., Summers, L. H., \& Waldmann, R. J. (1990). Noise trader risk in financial markets. Journal of Political Economy, 98, 703-738.

Elster, J.(1989). Social Norms and Economic Theory. Journal of Economic Perspectives, 3(4), 99-117.

Fan, G., Wang, X., \& Zhu, H.(2011). China's marketization index - relative process of marketization in various regions 2011 report. Beijing: Economic Science Press.

Grullon, G., Michenaud, S., \& Weston, J. P. (2015). The real effects of short-selling constraints. Review of Financial Studies, 28(6), 1737-1767.

Hammersley, J. S., Myers, L. A., \& Catherine, S. (2008). Market reactions to the disclosure of internal control weaknesses and to the characteristics of those weaknesses under section 302 of the Sarbanes Oxley Act of 2002. Review of Accounting Studies, 13(1), 141-165.

Hutton, A. P., Marcus, A. J., \& Tehranian, H. (2009).Opaque financial reports, $\mathrm{R}^{2}$, and crash risk. Journal of Financial Economics, 94(1), 67-86.

Jiang, F., Shi, B., \& Li, X.(2015). Is "honest" enterprise honesty? empirical evidence based on earnings management. Accounting Research, (8), 24-31.

Jin, L., \& Myers, S. C. (2006). R2 around the world: new theory and new tests. Journal of Financial Economics, 79(2), 257-292.

Joh, S. W. (2003). Corporate governance and firm profitability: evidence from Korea before the economic crisis. Journal of Financial Economics, 68(2), 287322.

Johnson, S., Porta, R. L., \& Shleifer, A. (2000). Tunneling. American Economic Review, 90(2), 22-27.

Kim, J. B., Li, L., Lu, L. Y., \& Yu, Y. (2016). Financial statement comparability and expected crash risk. Journal of Accounting \& Economics, 61 (2-3), 294-312

Kim, J. B., Li Y., \& Zhang, L.(2011). CFOs versus CEOs: equity incentives and crashes. Journal of Financial Economics, 101(3), 713-730.

Kim, J. B., \& Zhang, L. D.(2012). Accounting conservatism and stock price crash risk: firm-level evidence. Contemporary Accounting Research, 33(1), 412-441.

Kothari, S. P., Shu, S., \& Wysocki, P. D. (2009). Do managers withhold bad news? Journal of Accounting Research, 47(1), 241-276.

Mitra, S., Jaggi, B., \& Hossain, M. (2013). Internal control weaknesses and accounting conservatism evidence from the Post-Sarbanes-Oxley period. Journal of Accounting Auditing \& Finance, 28 (2), 152-191.

Morck, R., Yeung, B., \& Yu, W. (2000). The information content of stock markets: why do emerging markets have synchronous stock price movements? Journal of Financial Economics, 58(1), 215-260.

Murphy, P. E. (1998). Eighty exemplary ethics statements . Notre Dame: IN: University of Notre Dame Press.

O'Reilly, C., \& Chatman, J. (1986). Organizational commitment and psychological attachment: the effects of compliance, identification, and internalization on prosocial behavior. Journal of Applied Psychology, 71(3), 492-499.

Piotroski, J. D., Wong, T. J., \& Zhang, T. (2015). Political incentives to suppress negative information: evidence from Chinese listed firms. Journal of Accounting Research, 53(2), 405-459.

Plous, S. (1993). The psychology of judgment and decision making. New York, NY, England: Mcgraw-Hill Book Company.

Putnam, R. (1993).The prosperous community: social capital and public life. The American Prospect, 13 (1), $35-42$.

Ross, E. A. (1901). Social Control. American Journal of Sociology, 1(5), 513-535.

Sapienza, P., \& Zingales, L. (2012). A trust crisis. International Review of Finance, 12(2), 123-131.

Shleifer, A., \& Vishny, R. W. (1997). A Survey of corporate governance. Journal of Finance, 52(2), 737-783.

Song, L.(2015). Accounting disclosure, stock price synchronicity and stock crash risk: an emergingmarket perspective. International Journal of Accounting \& Information Management, 23(4), 349363.

Stout, L. (2002).The Investor Confidence Game. Brooklyn Law Review, 68 (2), 407 - 437.

Tian, L., \& Wang, K. (2017). The "cover-up effect" of social responsibility information disclosure and the collapse risk of listed companies: DID-PSM analysis from Chinese stock market. Management World, (11), 146-157.

Wang, X., Fan, G., \& Yu, J. (2017). China provincial marketization index report 2016. Beijing: Social Science Literature Publishing House.

Wang, Y. (2014). Cultural differences and M\&A performance of "honesty and innovation values": based on empirical data of equity M\&A events of listed companies in Shanghai and Shenzhen from 2008 to 2010. Accounting Research, (9), 74-80.

Wurgler, J. (2001). Financial markets and the allocation of capital. Journal of Financial Economics, 58(1-2), 187214. 
Xu, N., Jiang, X., Chan, K. C., \& Yi, Z. (2013). Analyst coverage, optimism, and stock price crash risk: evidence from china. Pacific Basin Finance Journal, $25,217-239$.

Zhai, S., Li X., \& Xu Y. (2015).Enterprise culture and commercial credit: does "honesty" play a role?
Contemporary Finance and Economics, (6), 118-128. Zhang, W. (2001). Property rights, government and credit. Shanghai: Sanlian Bookstore.

Zhang, W., \& Ke, R. (2002).Trust and explanation: interprovincial investigation and analysis from China. Economic Research Journal, (10), 59-70+96 